\title{
FUNGSIONALISASI TEORI NASKH DALAM TAFSIR AL-QUR'AN DAN HUKUM ISLAM: SEBUAH CATATAN KRITIS
}

\author{
Wardani \\ Dosen Tafsir Hadis Fakultas Ushuluddin dan Humaniora \\ IAIN Antasari Banjarmasin
}

\begin{abstract}
The commonly accepted assumption among Muslim scholars is that the abrogation (naskh) theory is regarded as method necessary for interpreting the Qur'an and for law-making. This article is aimed to explore how it has been used and abused to support ideological interest. From the beginning, some traditions, which are contradictory to each other, ascribed to 'Alî bin Abî Thâlib, for instance, which supports the importance of knowledge on naskh, falls under unreliable category. The traditions have been distorted and interpreted in different context to argue for its importance. The naskh has been used to interpret some ambigous verses, such as what Ahmad Al-Bahrânî, a Shiite scholar, to set up his own theological beliefs. Meanwhile, the Muslim jurists have applied it as a method of making of law decision. 'Abdullâh al-Karkhî (w. 340 H), a Hanafite scholar, for instance, used it to attack against legal opinions of non-Hanafite scholars. Since al-Shâfi'î́s era till contemporary time, the naskh has been regarded as a method of developing Islamic law, of course, in different contexts and trends.
\end{abstract}

Kata kunci: naskh, nâsikh, mansûkh

\section{Pendahuluan}

Dalam studi ilmu-ilmu al-Qur'an ('ulum al-Qur'ân), persoalan penganuliran (naskh) adalah salah satu persoalan yang sejak zaman klasik hingga modern tetap menjadi kontroversi yang tak kunjung berujung dan tetap memicu kontroversi. Intensitas debat tentang persoalan ini tercermin, antara lain, dari banyaknya karya tokoh Islam dan Barat tentang ini. Al-Zarkashî (w. $794 \mathrm{H}$ ), penulis al-Burhân fî Ulùm al-Qur'ân, misalnya, menyebut karya-karya yang ditulis hingga masanya tentang masalah ini, seperti: karya Qatâdah bin Di’âmah al-Sadûsî (w. 118 H), Abû 'Ubayd al-Qâsim bin Sallâm (w. 224 H), Abû Ja'far al-Nahhâs (w. 338 H), Hibatullâh bin Salâmah (w. 410 H), Ibn al-'Arabî (w. 546 H), Ibn al-Jawzî (w. 597 H), dan Makkî al-Qaysî (w. 313 H). ${ }^{1}$ Penelitian yang dilakukan oleh Mushthafâ Zayd dalam al-Naskh fí al-Qurân al-Karim menyebut sejumlah karya ulama di abad ke-2 H/ $8 \mathrm{M}$, termasuk yang masih dalam bentuk manuskrip tentang naskh. ${ }^{2}$ Salah satu isu menarik dalam konteks ini adalah bagaimana naskh dimapankan melalui sumber-sumber athar, dan difungsionalisasikan untuk berbagai kepentingan yang bersifat ideologis, baik dalam konteks tafsir al-Qur'an dan metode hukum Islam.

${ }^{1}$ Badr al-Dîn al-Zarkashî, al-Burhân fî̀ Ulûm al-Qur'ân, ed. Muhammad Abû al-Fahl Ibrâhîm, vol. 1 (Cairo: Dâr I hyyầ alKutub al-'Arabîyah, 1957 M/ 1376 H), 9.

${ }^{2}$ Lihat Mushthafâ Zayd, al-Naskh fî al-Qur'ân al-Karîm: Dirâsah Tashrî̀yyah Târîkhîyah Naqdîyah, vol. 1(Cairo: Dâr al-Yusr, 2007 M/ 1428 H), 306-418; Abû 'Abdillâh Shu'lah, Shafwat al-Râsikh fí Tlm al-Mansûkh wa al-Nâsikh (T.tp.: Maktabat al-Thaqâfah al-Dînîyah, 1995), 54-67; Sha'bân Muhammad 'Ismâ'îl, Naz̧harîyat al-Naskh fî al-Sharâ i’ al-Samâwîyah (T.tp.: Dâr al-Salâm,1988),

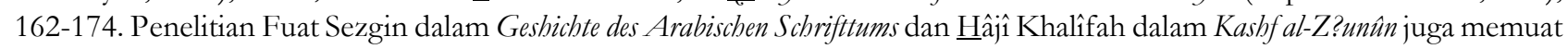
pemetaan karya-karya yang telah ditulis tentang naskh. 


\section{Pengetahuan tentang Naskb dalam Penafsiran al-Qur'an}

Qatâdah, penulis awal, sama sekali tidak mengemukakan uraian tentang pentingnya jenis bahasan ini dalam 'ulùm al-Qur ân, tapi hanya mengemukakan daftar ayat-ayat nâsikh-mansûkh. Uraian tentang hal ini dikemukakan oleh penulis-penulis lain. Secara historis, pendapat yang beredar berkaitan dengan penekanan pentingnya pengetahuan tentang naskh sebagai syarat yang harus ada (conditio sine qua non) untuk menafsirkan mengalami perkembangan:

a. Abû 'Ubayd (w. 223 H/ 838 M) dalam Kitâb al-Nâsikh wa al-Mansûkh mengemukakan tentang keutamaan ilmu tentang nâsikh dan mansûkh riwayat melalui 'Abd al-Rahmân bin Mahdî (w. 198 H/ 813-814 M) - Sufyân al-Thawrî (w. 161 H/ 778 M) - Abû ㅂashîn (w. 132 H/ 749 M atau 127-128 H/ 744-745 M) - Abû 'Abd al-Rahmân 'Abdullâh ibn ㅂaîib ibn Rabî'ah al-Sulamî (w. 73/74 H) dari 'Alî bin Abî Thâlib sebagai berikut:

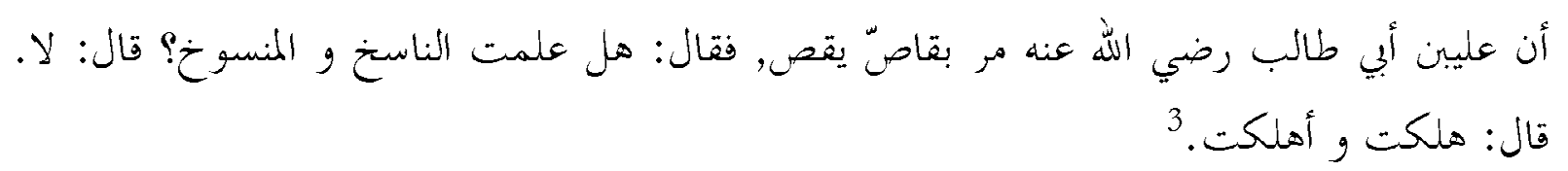

Bahwa 'Alî bin Abî Thâlib radhiyallâh 'anhu pernah melewati seorang pencerita yang sedang bercerita, kemudian ia bertanya, "Apakah kamu mengetahui nâsikh dan mansûkh? Orang tersebut menjawab, "Tidak". Alî berkata, "Kamu celaka dan mencelakakan orang lain".

Versi riwayat lain yang dikemukakan berasal dari al-Dhahhâk bin Muzâhim tidak berkaitan dengan 'Alî, melainkan Ibn 'Abbâs dengan kejadian yang sama. Di samping itu, Abû 'Ubayd juga mengemukakan riwayat Ibn 'Abbâs tentang tafsir kata " $\underline{b i k m a b " ~(Q .2 / 87: 269) ~ s e b a g a i ~}$ pengetahuan tentang aspek-aspek al-Qur`an, termasuk aspek naskh. ${ }^{4}$ Menurut Abû 'Ubayd, ta wîlyang berkaitan dengan penentuan makna sesungguhnya hanya diketahui oleh Tuhan (Q.3/ 89:7) yang kebenarannya jelas hanya pada hari kiamat, tapi tidak menutup pintu ta 'mîl sekarang terhadap naskh dalam al-Qur'an (ta wîl al-naskh fî al-tanzîl). ${ }^{5}$ Meskipun tafsîr-fiqh tidak bisa dipisahkan, naskh pada tahap ini lebih dimaknai sebagai instrumen penafsiran. Penjelasan Abû 'Ubayd ini kemudian dikutip oleh penulis-penulis sesudahnya, antara lain al-Muhâsibî dalam Fabm al-Qur'ân. ${ }^{6}$

\footnotetext{
${ }^{3}$ Abû 'Ubayd, Kitâb al-Nâsikh wa al-Mansûkh, suntingan (tahqî́q) Mushthafâ 'Abd al-Qâdir 'Athâ'. Beirut: Dâr al-Kutub al'Ilmîyah, 2006, 3.

${ }^{4}$ Banyak penafsiran yang berkembang tentang makna “bikmah”. Para mufassir umumnya, seperti Ibn Kathîr, al-Qurthubî, dan al-Khâzin, menafsirkan dengan beberapa pengertian: (1) sunnah Rasulullah saw. dengan bertolak dari riwayat Qatâdah, (2) pengetahuan tentang agama Islam dan hukum-hukumnya, (3) kebenaran dalam bertutur. Ibn Kathîr, Tafsîr al-Qur'ân al-'Az?îm (Beirut: Dâr al-Fikr, t.th.), vol. 1, 185; al-Qurthubî, al-Jâmi' li A hlkâm al-Qur ân, vol. 2 (T.tp.: t.p. t.th.), 131; al-Khâzin, Lubâb alTa 'wîl fî̀ Ma'ânî al-Tanzîl, vol. 1 (Beirut: Dâr al-Kutub al-'Ilmîyah, 1995), 148. Tentang penafsiran Sunnî dan Shî'ah, lihat Îhâb Hasan 'Abduh, Istihâlat Wujûd al-Naskh (Dirâsah Tlmîyah Tudbidh Khurâfât al-Riwâyât wa Taruddu 'alâ Jahl Zakariyyâ Buthrus. Cairo: Maktabat al-Nâfidhah, 2005), 96-98. Dalam beberapa riwayat hadîth, al-hikmah ditafsirkan sebagai al-Quran sendiri. Pada Q.2/ 87:269, al-hikmah adalah sesuatu yang dianugerahkan Tuhan dan merupakan sumber kebaikan. Hal ini ditopang oleh pernyataan hadîth " alayka bi al-bikemah, fa inna al-khayrfí al-hikemah". Pernyataan ini dikutip sebagai hadîth dalam Seyyed Hossein Nasr, "The Meaning and the Concept of Philosophy in Islam," dalam Seyyed Hossein Nasr dan Oliver Leaman (eds.), History of Islamic Philosophy, vol. 1 (London dan New York: Routledge, 1996), 21. Pernyataan ini dalam Sunan al-Dârimî (bab "al-tawbîkh li man yathlub al- 'ilm li ghayr Allâh”) disebut berasal dari pernyataan Wahb bin Munabbih kepada anaknya. Dalam hadîth lain, al-bikikmah diartikan sebagai "menemukan kebenaran di luar petunjuk kenabian" (al-ishâbah fi ghayr al-nubûwah) (al-Bukhârî, Shabîhbal-Bukhârî, anotasi (ta’liá) Mushthafâ Dîb al-Bighâ, vol. 3 (Beirut: Dâr Ibn Kathîr, 1407 H/ 1987 M), 1371.

${ }^{5}$ Penjelasan Abû Ubayd di awal karyanya ini lebih difokuskan untuk menjelaskan bahwa persoalan naskh adalah persoalan ta wîl. Abû 'Ubayd, Kitâb al-Nâsikh wa al-Mansûkh, 3-4.

${ }^{6}$ al-Muhâsibî, Fahm al-Qur'ân (Ed.
} 
b. Abû Ja'far al-Nahhâs (w. 338 H/ 950 M) di samping mengemukakan riwayat al-Sulamî, juga riwayat Abû al-Bakhtarî (w. $83 \mathrm{H})^{7}$ yang sama-sama disisipi keterangan (interpretasi) "bercerita" tersebut sebagai "memberi nasihat" atau "memberi peringatan kesadaran keagamaan" dan menambah dengan pernyataan Hudhayfah tentang tiga orang yang berhak memberi fatwa, di antaranya orang yang mempelajari ayat-ayat yang mansûkh dalam al-Qur'an, yaitu 'Umar bin alKhaththâb ketika itu. ${ }^{8}$ Naskh di sini sudah mulai masuk ke wilayah kesadaran figh.

c. Hibatullâh (w. 410 H/ 1019 M) mengemukakan riwayat yang sama disertai dengan penjelasan bahwa orang tersebut adalah teman Abû Mûsâ al-Ash'arî yang bernama 'Abd al-Rahmân bin Dâb dengan panggilan Abû Yahyâ. Hibatullâh menganggap pentingnya pengetahuan naskh lebih karena "mengikuti imam-imam salaf", karena hal itu sudah menjadi kewajiban yang diterima dan ditransmisikan dari generasi awal Islam. Pada tahap ini, pentingnya pengetahuan naskh sudah diterima secara mapan (established). Oleh karena itu, ia mengatakan:

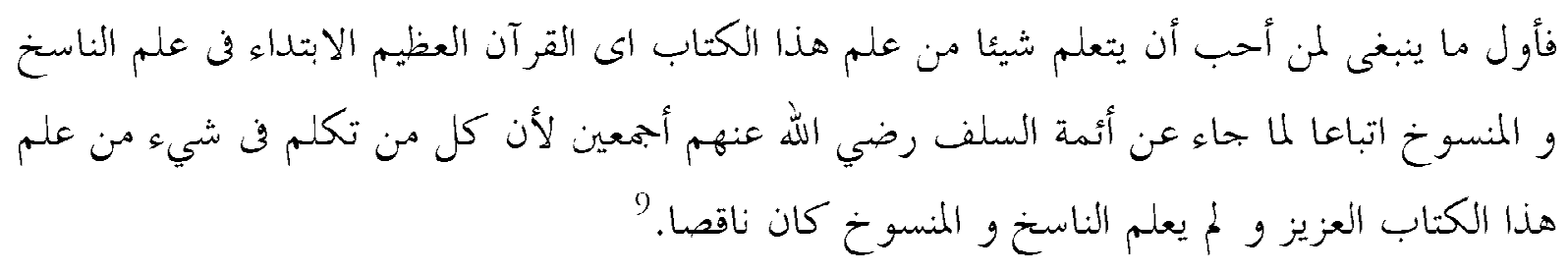

Hal pertama yang mesti dilakukan oleh orang yang ingin mempelajari sesuatu dari pengetahuan tentang kitab suci ini, yaitu al-Qur'an yang agung, adalah memulainya dari pengetahuan tentang nâsikh dan mansûkh, karena mengikuti apa yang berasal dari imam-imam salaf, radhiyallahb 'anhum ajma'în, karena siapa yang berbicara tentang sesuatu apa pun yang berkaitan dengan pengetahuan tentang kitab suci yang mulia ini, sedangkan ia tidak mengetahui nâsikh dan mansûkh, menjadi kurang.

Hibatullâh tidak hanya menganggap bahwa pengetahuan tentang naskh menempati posisi utama, karena menjadi hal pertama yang harus dipelajari di antara cabang-cabang ilmu tentang al-Qur'an, melainkan juga menegaskan urgensi tersebut dengan mengangkat klaim penerimaan "salaf” terhadap naskh, seperti dijustifikasi dengan keterangan Abû 'Ubayd di atas, ke level normatif, padahal ide tentang salafíyah, meski memiliki sisi-sisi normativitas, juga merupakan sebuah eksperemen historis generasi awal Islam. ${ }^{10}$ Pandangan Hibatullâh ini mempengaruhi penulis-penulis lain, antara lain Mar'î bin Yûsuf al-Karamî (w. 1033 H) dalam Qalâiid al-Marjân, tentang pengetahuan tentang naskh yang diidentikkan dengan pengetahuan halal-haram. ${ }^{11}$

d. Semasa dengan Hibatullâh (abad ke-5 H) juga, muncul karya yang dinisbatkan kepada otoritas seorang tâbî̀, yaitu al-Zuhrî, melalui riwayat seorang shûfî, Abû 'Abd al-Rahmân Muhammad

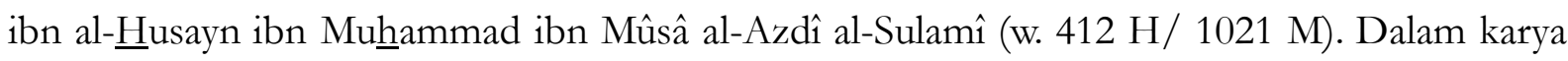

${ }^{7}$ Menurut Yahyâ bin Ma’în, Abû al-Bakhtarî sama sekali tidak menerima riwayat dari 'Alî. Lihat al-Mizzî, Tahdhîb al-Kamâl, vol. 11, ed. Bashshâr 'Awwâd Ma’rûf, vol. 11 (Beirut: Mu`ssasat al-Risâlah, 1982), 32-34.

${ }^{8}$ al-Nahhâs, al-Nâsikh wa al-Mansûkh, (Cairo: al-Maktabah al-Azharîyah, t.th.), 11-12.

${ }^{9}$ Hibatullâh ibn Salâmah, al-Nâsikh wa al-Mansûkh, suntingan (tậqîq) Zuhayr al-Shâwîs dan Muh?ammad Kan'ân (Beirut: al-Maktab al-Islâmî, 1404 H), 4-6. Menurut riwayat Hibatullâh, tanpa menyebut sanad, 'Alî menjewer telinga orang tersebut. Sedangkan, riwayat melalui al-Dhahhâk bin Muzâhim menjelaskan bahwa 'Alî menendang orang tersebut sebelum bertanya. Ibn Shihâb al-Zuhrî, al-Nâsikh wa al-Mansûkkh, 16.

${ }^{10}$ Lihat Muhammad Sa'îd Ramadhân al-Bûthî, al-Salafìyah: Marhalah Zamanîyah Mubârakah, Lâ Madhhab Islâmî (Damaskus: Dâr al-Fikr, 1990). Bandingkan dengan Shâlih bin Fawzân bin 'Abdullâh al-Fawzân, Ta' qîbât' 'alâ Kitab al-Salafîyah Laysat Madhbaban (Riyâdh: Dâr al-Wathan li al-Nashr, $1411 \mathrm{H}$ ).

${ }^{11}$ al-Karamî, Qalâ 'id al-Marjân fî̀ Bayân al-Nâsikh wa al-Mansûkh fî al-Qur'ân, 1 (dalam www.elmeshkat.com). 
ini, juga dikemukakan riwayat yang sama. ${ }^{12}$ Justifikasi pentingnya naskh melalui otoritas awal ini diragukan karena penisbatan karya ini sebagai karya al-Zuhrî juga diragukan. Fuat Sezgin dalam Geschichte des Arabischen Schrifttums mencantumkan karya ini sebagai karya al-Zuhrî. ${ }^{13}$ Menurut perkiraan Wansbrough, manuskrip yang difoto oleh Sezgin dari Perpustakaan Umum Bâ Yazîd (Beyazit) nomor 445 sebenarnya adalah al-Nâsikh wa al-Mansûkh karya 'Abd al-Qâhir al-Baghdâdî (w. 429 H/ 1038 M). ${ }^{14}$ Begitu juga, menurut Hilmî Kâmil, salah satu di antara dua manuskrip karya al-Baghdâdî adalah naskah mikrofilm di al-Markaz al-Tlmî di Universitas King Abdul 'Azîz Makkah nomor 448/tafsîr wa 'ulûm al-Qur'ân yang difoto dari naskah di Ma'bad alMakbthûthât di Jâmi'at al-Duwal al-'Arabîyah nomor 265/tafsîr. Naskah ini berasal dari naskah aslinya di Perpustakaan Umum Bâ Yazîd (Beyazit) di Istanbul nomor 445. ${ }^{15}$ Kekeliruan tersebut mungkin disebabkan oleh kekeliruan dalam menyalin (copy) dari Fibrist al-Makbthâthât alMushawwarah di Cairo. ${ }^{16}$ Manuskrip kedua yang disebut Sezgin sebenarnya adalah manuskrip koleksi Yahuda nomor 228/2 di Universitas Princeton. Manuskrip ini difoto dan hasilnya disimpan bersama dengan Tanzîl al-Qur ân bi Makkah wa al-Madînah yang disunting oleh SHalâh al-Dîn al-Munajjid pada tahun 1963 oleh Dâr al-Kutub al-Mishrîyah nomor $1084 .{ }^{17}$ Menurut Mushthafâ Zayd, pada lembar-lembar awal karya ini yang berbicara tentang pentingnya pengetahuan tentang naskh, terdapat riwayat 'Alî dan Ibn 'Abbâs yang sanadnya berujung pada al-Walîd bin Muhammad al-Mûqirî (w. $182 \mathrm{H}$ ), seorang rawi yang sudah disepakati oleh para kritikus (naqqâd) sebagai rawi yang pendusta dan memalsukan riwayat atas nama al-Zuhrî, serta menyebut mursal sebagai marfû́, dan yang mawqûf sebagai musnad. Dengan demikian, karya ini tidak bisa dipertimbangkan sebagai karya yang orisinal dari al-Zuhrî. Sedangkan, karya lain yang ditulis oleh sufi Abû 'Abd al-Rahmân al-Sulamî (Muhammad ibn alMuhammad) dengan menisbatkan riwayat kepada al-Zuhrî, tapi juga melalui al-Mûqirî, hal tersebut tidak mengubah statusnya sebagai pemalsuan. ${ }^{18}$ Dengan demikian, jelas bahwa karya tersebut bukan karya orisinal al-Zuhrî, melainkan dinisbahkan kepadanya oleh tokoh belakangan. Itu artinya bahwa penjelasan di dalamnya tentang pentingnya naskh juga merupakan kreasi belakangan. Dengan justifikasi otoritas al-Zuhrî dan diperkuat dengan otoritas-otoritas lain, seperti Abû 'Ubayd, pentingnya ilmu tentang naskh diterima luas pada abad ini.

e. Al-Ja'barî dalam Rusûkh al-A $\underline{h} b a \hat{r}$ menyatakan bahwa pengetahuan tentang naskh adalah kewajiban kolektif yang bisa dilaksanakan meski hanya oleh sebagian kaum muslim (fardhu kifâyah), karena sebagian hukum Islam hanya bisa dijelaskan dengan naskh dengan mengutip secara fiktif pernyataan al-Zuhrî, "Siapa yang tidak mengetahui nâsikh dan mansûkh, ia melakukan

${ }^{12}$ Ibn Shihâb al-Zuhrî, al-Nâsikh wa al-Mansûkh, edisi Hâtim Shâlih al-D?âmin, Silsilat Kutub al-Nâsikh wa all-mansûkkh, 15.
${ }_{13}$ "an-Nâsih wa-l-mansûh fi l-Our'ân bearbeitet von al-Hus. B. M. as-Sulamî (st.412/1021, s.u. S. 671) Beyazit 445 (16 ff., 7. Jh. H., vgl. Fibr. mht. I, 48), Princeton, Coll. von Yehuda 228/2". Fuat Sezgin, Geschichte des Arabischen Schrifttums, band 1 (Leiden: E.J. Brill, 1967), 283. 1977), 199.

${ }^{14}$ John Wansbrough, Quranic Studies:Sources and Methods of Scriptural Interpretation(Oxford: Oxford University Press,

${ }^{15}$ Hilmî Kâmil As'ad 'Abd al-Hâdî, "Bayn Yaday al-Makhthûth”, dalam 'Abd al-Qâhir al-Baghdâdî, al-Nâsike wa alMansûkh, suntingan (tậqîq) Hilmî Kâmil As'ad 'Abd al-Hâdî (Aman: Dâr al-'Adawî, t.th.), 27.

${ }^{16}$ Andrew Rippin, "Al-Zuhrî, Naskh al-Qur'ân, and the Problem of Early Tafsir Text", dalam Bulletin of the School of Oriental and African Studies, University of London, volume 47, no. 1 (1984), 25.

${ }^{17}$ Andrew Rippin, "Al-Zuhrî, Naskh al-Qur 'ân..," 25; Hâtim Shâlih al-Dhâmin, "al-Zuhrî wa Kitâbuh", dalam al-Zuhrî, al-Nâsikh wa al-Mansûkh, 8.

${ }^{18}$ Mushthafâ Zayd, al-Naskh fí al-Qur'ân al-Karîm, vol. 1, (Cairo: Dâr al-Yusr, 2007), 313-315. Bandingkan dengan Mushthafâ Mahmûd al-Azharî, "Tawthîq Nisbat al-Kitâb li al-Zuhrî”, dalam Ibn Shihâb al-Zuhrî, al-Nâsikh wa al-Mansûkh, 21-23. 
pencampuradukkan dalam agama" (من لم يعلم الناسخ و المنسوخ خلط في الدين) Pernyataan tersebut juga dikutip Shu'lah dalam SHafwat al-Râsikh. ${ }^{20}$ Padahal, sejauh penelitian yang dilakukan oleh $\underline{H}$ asan Muhammad Maqbûlî al-Ahdal dalam disertasinya tentang naskh karya al-Ja'barî, alZuhrî tidak pernah mengucapkan hal itu, ${ }^{21}$ kecuali pernyataannya "Para fuqahâ" tidak bisa menghindar dari keharusan mengetahui mana hadîth Rasululllâh saw. yang nâsikeh dan yang

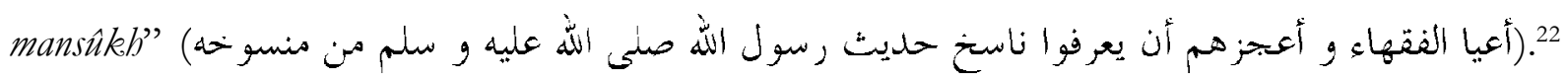

Dengan demikian, pentingnya pengetahuan tentang naskh mengalami perkembangan, dari sumber yang diklaim berasal dari sahabat Nabi, terutama 'Alî dan Ibn 'Abbâs, ditransmisikan, ditafsirkan, dan mengalami distorsi. Peristiwa 'Alî di masjid Kûfah adalah rujukan athar yang paling populer. Peristiwa tersebut, seperti tampak pada kutipan Abû 'Ubayd, semula berkaitan dengan

konteks "pencerita" (qâshsh, قَاصٌ), meskipun kemudian terdistorsi, selain mungkin karena proses suntingan (tahlqî) penyunting, juga karena persoalan tafsiran, menjadi "pemberi keputusan hukum" (qâdhin, قَاض..$^{23}$

Apa hubungan antara bercerita dengan naskh? Pada awal Islam, bercerita adalah media untuk menyampaikan ajaran Islam, tapi kemudian diselewengkan. Dari perbedaan respon ulama terdahulu, seperti 'Umar, 'Alî, Ibn Mas'ûd, Ibn 'Abbâs, 'Â ishah, Abû al-Dardâ', Ibn Sîrîn, Ibn Qutaybah, alGhazâlî, Sufyân al-Thawrî, Mâlik, Ibn Muflihn, al-'Irâqî, dan al-Suyûthî, keberadaan pencerita mengalami perkembangan. ${ }^{24}$ Secara historis, hal ini bisa dilihat dari perkembangan alasan dan kondisinya. Pertama, alasan dan kondisi keagamaan. Menurut keterangan Ibn 'Umar, komunitas pencerita muncul setelah masa pemerintahan 'Umar bin al-Khaththâb. Akan tetapi, ada bukti bahwa komunitas ini muncul pada masa 'Umar. Diriwayatkan bahwa Tamîm al-Dârî adalah pencerita pertama yang diakui pada masa 'Umar. Namun, pada masa ini pula sudah terjadi penyimpangan tujuan dalam bercerita, misalnya, ketika ada berita tentang keberadaan pencerita di Basrah, ia mengirim surat berisi Q.12/53:1-3 yang

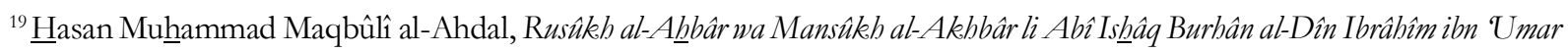
al-ja'barî: Dirâsah wa Tặqîq (Beirut: Mu’assasat al-Kutub al-Thaqâfîyah dan San'â: Maktabat al-Jîl al-Jadîd, 1988 M/ 1408 H.), 128. Belakangan, pernyataan tersebut dikutip dalam 'Izz al-Dîn Husyan al-Shaykh, Mukhtashar al-Nâsikh wa al-Mansûkh fî $\underline{H}$ adîth Rasulillâh Shallâ Allâh 'Alayh wa Sallam (Beirut: Dâr al-Kutub al-'Ilmîyah, 1993), 3.

${ }^{20}$ Shu'lah, Shafwat al-Râsikh fî Tlm al-Mansûkh wa al-Nâsikh, suntingan dan studi (tậqîq wa dirâsab) Muhammad Ibrâhîm 'Abd al-Rahmân Fâris. Ayn Shams: Maktabat al-Thaqâfah al-Dînîyah, 1995, 97.

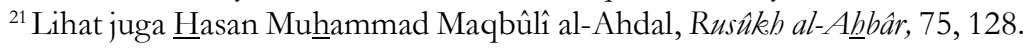

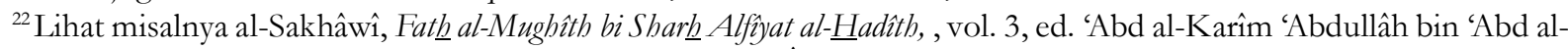
Rahmân al-Khudhayr dan Muhammad bin 'Abdullâh bin Fuhayd Âl Fuhayd (Riyâdh: Maktabat Dâr al-Minhâj, 1426 H), $445-$

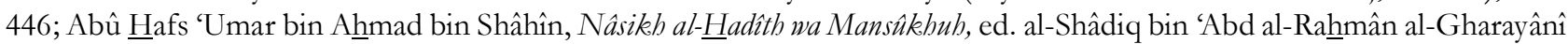

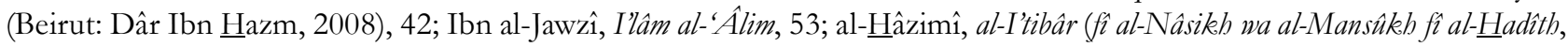
suntingan (tahqî́q) disertai studi Ahmad Thanthâwî Jawharî Musaddad. Makkah: al-Maktabah al-Makkîyah dan Beirut: Dâr Ibn Hazm, 2001), 114; Abû Nu'aym, ㅂilyat al-Awliyâ wa Thabaqât al-Ashfiyầ, vol. 3(Beirut: Dâr al-Kutub al-'Ilmîyah, 1988), 365; alSuyûthî, Tadrîb al-Râwî fî Shark Taqrîb al-Nawâwî̀, ed. al-Shaykh 'Arafât al-'Ashshâ Hishshûnah (Beirut: Dâr al-Fikr, 1993$), 361$.

${ }^{23}$ Lihat misalnya al-Suyûthî, al-Itqân fì 'Ulûm al-Qur'ân, vol. 1 (Beirut: Dâr al-Fikr, t.th.), 20; al-Hazimî, al-Nâsikeh wa alMansûkh fî al-Qur'ân, suntingan (tạqqî) 'Abd al-Ghaffâr Sulaymân al-Bindârî. Beirut: Dâr al-Kutub al-'Ilmîyah, 1986), 5; Ibn alJawzî, al-Mushaffâ bi Akuff Ahl al-Rusûkeh min Tlm al-Nâsikh wa al-Mansûkkh. Dalam Hâtim Shâlih al-Dhâmin (ed.). Silsilat Kutub al-Nâsikh wa al-Mansûkh, 13. Dalam karyanya yang lain, Ibn al-Jawzî mencantumkan delapan riwayat yang secara jelas menunjukkan bahwa yang dimaksud adalah "pencerita" (qâshsh), bahkan di antara riwayat tersebut ada yang merupakan versi pengakuan Abû Yahyâ sendiri. Ibn al-Jawzî, Nawâsikh al-Qur ân (Dâr al-Kutub al-'Ilmîyah, t.th), 29-32. Sedangkan, al-Nahhâs mencantum kedua versi ini bersamaan. Lihat al-Nahhâs, al-Nâsikh wa al-Mansûkh, edisi al-Maktabah al-Azharîyah, 12. Lihat juga Muhammad Hâdî Ma'rifah, al-Tambîdfî 'Ulûm al-Qur ân, vol. 2(Qom: Mu assasat al-Nashr al-Islâmî, 1411 H), 275-276.

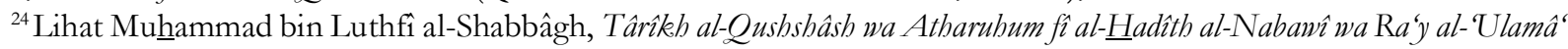
fỉhim (al-Maktab al-Islâmî, 1985), 48-64. 
menyatakan bahwa cerita-cerita al-Qur`an lah yang merupakan cerita-cerita terbaik (absan al-qashash). Bercerita kemudian dianggap sebagai merakayasa fakta, sehingga ia pernah mencambuk seorang pencerita karena alasan ini. ${ }^{25}$ Begitu juga, dalam literatur-literatur hadîth kemudian, seperti ditekankan oleh Ibn Qutaybah dalam Ta wîl Mukhtalif al- $\underline{H}$ adîth, pencerita dianggap sebagai sumber hadîthhadîth $d h a^{\prime} \hat{\imath} f{ }^{26}$ Kritik mubaddithûn juga tampak dalam karya al-Suyûthî, Tạhdhîr al-Khawâshsh min Akâdhîb al-Qushshâsh. ${ }^{27}$

Kedua, alasan dan kondisi keagamaan-politis. Komunitas pencerita muncul secara marak setelah terjadi fitnah (huru-hara politik) pada masa 'Uthmân bin 'Affân hingga berlanjut pada masa 'Alî bin Abî Ṭâlib. Dari perspektif keagamaan ketika itu, komunitas pencerita dianggap mengaburkan penjelasan yang benar tentang agama, seperti dengan menyisipkan mitos-mitos. Mereka masuk ke masjid-masjid sebagai pemberi nasihat dengan menyajikan cerita-cerita dan dongeng-dongeng. AlTabarî, al-Baghawî, dan al-Khâzin ketika menafsirkan "dan janganlah kamu mengusir orang-orang yang berdoa kepada tuhan mereka pada waktu pagi dan petang" (Q.6/55:52) mengemukakan riwayat Mujâhid bahwa ia pernah salat bersama Sa'îd ibn al-Musayyib, dan ketika imam salam, orang-orang bergegas mendekati seorang pencerita yang ada di masjid tersebut. ${ }^{28}$ Atas dasar ini, dalam beberapa riwayat, muncul kecamaan terhadap mereka seperti "menunggu celaan", "laknat", "mematikan ilmu", dan "pembuat bid'ab". Diriwayatkan juga bahwa Bani Isrâ‘îl telah dimusnahkan karena membuat cerita dengan merakayasa fakta. ${ }^{29}$ Ibn al-Jawzî dalam Talbîs Iblîs menuturkan bahwa pada masa awal, pencerita adalah para ulama yang ahli fiqh, seperti 'Ubayd bin 'Umayr yang majlisnya dihadiri oleh 'Abdullâh bin 'Umar. Begitu juga, 'Umar bin 'Abd al-'Azîz pernah menghadiri, bahkan mengadakan majlis pencerita. Namun, majlis pencerita, tegas Ibn al-Jawzî, berubah menjadi tempat berdusta. ${ }^{30}$ Dengan alasan seperti ini, 'Alî menguji pengetahuan keagamaan seorang pencerita yang ditemuinya di pasar Kûfah ${ }^{31}$ dan mengusir seorang yang tidak mengetahui nâsikh dan mansûkh di masjid di kota itu, seperti dalam riwayat di atas. Oleh karena itu, dari munculnya riwayat 'Alî di atas dari Abû 'Abd al-

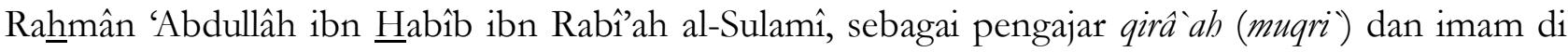
masjid Kûfah tersebut selama empat puluh tahun dan larangan al-Sulamî kepada 'Âshim untuk tidak mengikuti majlis pencerita, ${ }^{32}$ hingga sikap 'Abdullâh ibn al-Sâ'ib tidak mau sujud sajdah dari bacaan seorang pencerita, ${ }^{33}$ bisa dipahami dalam konteks ini. Namun, belakangan, seperti dijelaskan dalam 'Awn al-Ma'bûd, secara politis orang yang paling berhak menyampaikan cerita, nasihat, dan peringatan kemudian dibatasi hanya menjadi hak pemimpin atau orang yang didelegasikannya. ${ }^{34}$

${ }^{25}$ Ibn Abî Shaybah, al-Mushannaffí al-A Ahâdîth wa al-Âthâr, vol. 6 (Beirut: Dâr al-Fikr, 1994), 196-198.

${ }^{26}$ Lihat Ibn Qutaybah, Ta'wñl Mukhtalif al- $\underline{H}$ adîth, Cairo: Mu'assasat al-Kutub al-Thaqâfîyah, 1988, 358-364; Muhammad

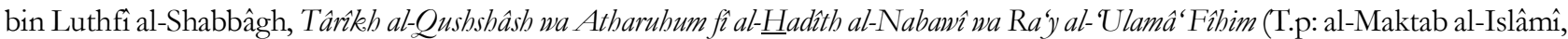
1985), 45-46.

${ }^{27}$ Lihat al-Suyûthî, Tạhdhîr al-Khawâshsh min Akâdhî̉ al-Qushshâsh (manuskrip dalam www.mostafa.com).

${ }^{28}$ al-Baghawî, Ma'âlim al-Tan₹îll, vol. 2(Beirut: Dâr al-Kutub al-'Ilmîyah, 1993), 81-82; al-Khâzin, Tafsîr al-Khẫin, vol. 2(Beirut: Dâr al-Fikr, t.th.), 18.

${ }^{29}$ al-Suyûthî, al-Durr al-Manthûr, ed. 'Abdullâh bin 'Abd al-Muhnsin al-Turkî, vol. 14 (Cairo: Markaz li al-Buhûth wa alDirâsât al-'Arabîyah wa al-Islâmîyah, 2003), 446.

${ }^{30}$ Ibn al-Jawzî, Talbîs Iblìs, ed. Muhyî al-Dîn Muhammad Ba’yûn (Beirut: Dâr Ibn Zaydûn, t.th.), 182-185.

${ }^{31}$ Abû Nu'aym, Hilyat al-Awliyấ', vol. 4 (Beirut: Dâr al-Kutub al-'Tlmîyah, 1988), 136.

${ }^{32}$ al-Dhahabî, Ma'rifat al-Qurrâ' al-Kibâr 'alâ al-T?abaqât wa al-A'shâr (Beirut: Dâr al-Kutub al-'Ilmîyah, 1997), 28; Ibn Abî Shaybah, al-Mushannaf, vol. 6 (Beirut: Dâr al-Fikr, 1994), 195.

${ }^{33}$ al-Bukhârî, Shậîh al-Bukhârî, vol. 1 (Beirut: Dâr al-Fikr, 1994), 41.

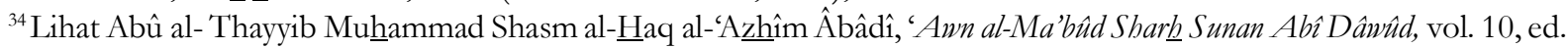
'Abd al-Rahmân Muhammad 'Uthmân (Beirut: Dâr al-Fikr, t.th.), 98-103. 
Ketiga, alasan status sosial-keagamaan. Profesi pencerita sebagai "pemberi nasihat" menjadi profesi yang dibanggakan di samping profesi-profesi keagamaan lain. Mujâhid mengatakan: "Kami bisa berbangga kepada orang banyak dengan status kami sebagai ahli fiqh (faqîh), ahli cerita (qâshsh), pengumandang adhân (mu'adhdhin), atau sebagai qâri". ${ }^{35}$ Komunitas pencerita, dengan demikian, menjadi tandingan dalam posisinya sebagai "pemberi nasihat" (wâ'į??) terhadap kelompok lain. Mungkin saja bahwa pernyataan Mujâhid tidak hanya menjelaskan konteks fase tâbi'ûn, melainkan juga konteks riwayat al-Sulamî dari 'Alî.

Dari perkembangan di atas, tidak ada petunjuk yang kuat bahwa naskh yang dimaksud oleh 'Alî adalah naskh al-Qur`an secara spesifik, kecuali hanya pencampur-adukkan yang dikhawatirkan dalam suatu penuturan cerita, yang sesuai dengan fakta bahwa generasi awal Islam (hingga abad ke-3 H) menggunakan istilah naskh dalam pengertian generik, yaitu menghilangkan ketidakjelasan, atau menjadikan sesuatu yang tidak jelas menjadi jelas. Makna naskh yang ditarik dari perkataan 'Alî ke makna naskh sekarang sebagai pembatalan ayat atau ke konteks hukum seperti tampak dari "tafsiran" riwayat-riwayat yang muncul sesudahnya adalah melalui inferensi atau penyimpulan yang terjadi dalam proses sejarahnya yang panjang seperti itu.

Al-Jâhizh dalam al-Bayân wa al-Tabyîn memang menunjukkan adanya hubungan antara tafsir dan komunitas pencerita di Basrah pada abad ke-2 H/ 8 M. Di antara mereka adalah Mûsâ ibn Sayyâr alUswârî dan Abû 'Alî 'Amr ibn Fâ’id al-Uswârî. Namun, seperti dicatat Claude Gilliot, kaitan qushshâsh dengan perkembangan awal tafsir al-Qur`an tidak signifikan. ${ }^{36}$

Munculnya pemahaman bahwa pengetahuan tentang nâsikh dan mansûkh dalam al-Quran sebagai syarat mutlak dalam menafsirkan al-Qur'an memicu perkembangan secara massif literaturliteratur naskh yang diproyeksikan sebagai handbook untuk dirujuk berkaitan dengan ayat-ayat yang nâsikh dan mansukkh. Namun, karena tentu saja bertolak dari ta'wîl para penulis, literatur-literatur naskh ditandai oleh kesimpulan jumlah ayat-ayat mansûkh dengan perbedaan yang menyolok.

\section{Naskb Sebagai Metode Ta'wîl al-Qur'an}

Fungsionalisasi naskh sebagai metode ta'wîl al-Qur'an tampak lebih menonjol di kalangan Shî’ah dan Mu'tazilah untuk kepentingan menjelaskan secara rasional prinsip-prinsip ajaran mereka. Formulasi yang komprehensif dan mewakili perkembangan terakhir pemikiran tentang hal ini dikemukakan oleh Shaykh Aḥmad al-Bahrânî, seorang Shî̀̂, dalam karyanya, al-Ta'wîl: Manhaj al-Istinbâth fì al-Islâm. Dengan idealisasi aliran (madrasah) Abl al-Bayt,ia mengkritik konsep naskh yang dikatakannya dipahami dengan pendekatan "aliran rasional" (madrasat al-ra y), seperti pada al-T?ûsi. ${ }^{37}$ Begitu juga, ia mengkritik al-Khû́î yang meski hampir menolak keberadaan naskh karena dipengaruhi oleh Abû Muslim alIshfahânî (w. $322 \mathrm{H}$ ), tapi masih mengulang definisi tersebut. ${ }^{38}$ Pemahaman yang berkembang, menurut

\footnotetext{
35 "Kunnâ nafkeharu 'alâ al-nâs bi arba'ah: bi faqîhinâ wa bi qâshshinâ wa bi mu adhdhininâ wa bi qâri inâ. Faqîhunâ Ibn 'Abbâs, wa

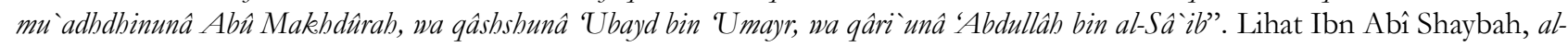
Mushannaf, vol. 6, 195.

${ }^{36}$ Claude Gilliot, "The Beginnings of Qur ânic Exegesis”, dalam The Qur an: Formative Interpretation, ed. Andrew Rippin (Great Britain: Ashagate, 1999), 22-23.

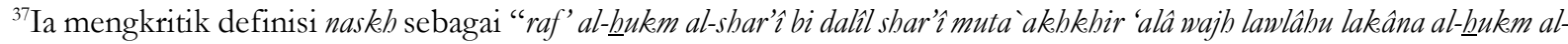
awwal thâbitan” yang diterima di kalangan Sunnî. Aḥmad al-Bahrânî, al-Ta 'wîl Manhaj al-Istinbâth fî al-Islâm (T.Tp.: Dâr al-Ta wîl li al- Thibâ'ah wa al-Nashr, 1999), 251.

${ }^{38}$ Ibid., 252. Lihat lebih lanjut al-Sayyid Abû al-Qâsim al-Mûsawî al-Khû'î, The Prolegomena to the Qur'an, terj. disertai pengantar oleh Abdulaziz A. Sachedina (Oxford: Oxford University Press, 1998),186-222.
} 
al-Bahrânî, hanya menempatkan naskh dalam bingkai teoretis, sehingga memicu kontroversi ketika penerapannya hanya berupa klasifikasi ayat-ayat nâsikh dan mansûk. ${ }^{39}{ }^{9}$

Meskipun ia mengakui perubahan pada bacaan ayat al-Qur'an (naskh al-tilâwah) yang disebutnya sebagai "pembatalan yang ditandai dengan penggantian" (al-naskh al-ibdâli) berupa penggantian

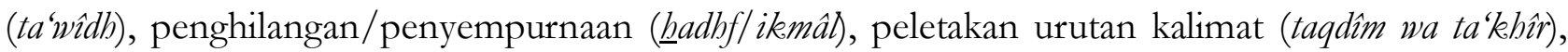
al-Bahrânî menekankan pada ide tentang teks bergerak (barakat al-nashsh) sebagai bagian dari pemikirannya tentang ta'wîl. ${ }^{40}$ Menurutnya, naskh adalah "gerak kandungan al-Qur'an" (ㅁarakat mukawwinât al-kitâb) sehingga tidak ada naskh permanen, melainkan hanya "naskh temporal" (naskh mu'aqqat) yang sasarannya bukan pembatalan teks, melainkan pergantian sementara makna atau aspekaspek makna yang terkandung dalam teks. Al-Bahrânî mengatakan sebagai berikut:

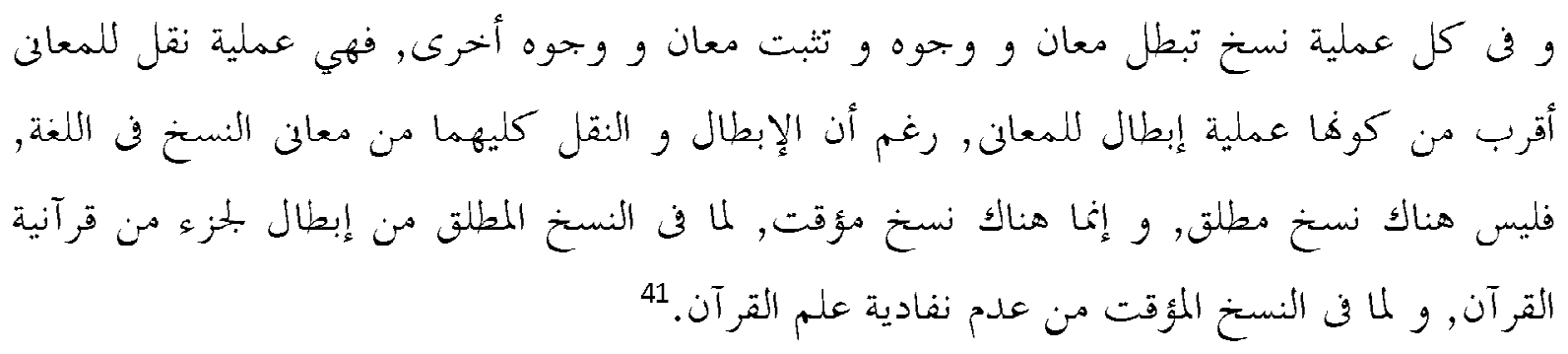

Dalam setiap pemberlakuan naskh, ada makna-makna dan aspek-aspek dari makna tertentu yang dibatalkan, diiringi dengan ditetapkannya makna-makna dan aspek-aspek dari makna lain. Pemberlakuan naskh lebih bisa dipahami sebagai upaya memindah makna-makna dibandingkan sebagai upaya membatalkannya, meskipun pembatalan dan pemindahan adalah bagian dari pengertian nask $h$ dari segi bahasa. Dengan demikian, tidak ada naskh mutlak, yang ada hanya naskh temporal, karena dalam naskh mutlak terkandung pengertian adanya pembatalan bagian tertentu dari jati diri al-Qur'an, sedangkan dalam naskh temporal terkandung pengertian tidak habisnya ilmu yang ada dalam al-Qur'an.

Bertolak dari kritiknya terhadap al-Thûsî (w. 672 H) dan al-Khû́î (w. 1413 H/ 1992 M) di atas, ia mengemukakan naskh sebagai metode ta'wîl. Versi berbeda tentang peristiwa 'Alî di masjid Kufah dikemukakan sebagai titik-tolak, yaitu bahwa 'Alî mengatakan kepada seorang pencerita tersebut "Kamu celaka dan mencelakakan orang lain, menta'wîkan setiap hurup dalam al-Qur'an berdasarkan beberapa aspek makna" (halakta wa ablakta, ta'wîl kull barf fî al-Qur'ân 'alâ wujûh). ${ }^{42}$ Menurut alBahrânî, 'Alî mengaitkan antara pengetahuan tentang naskhb dengan ta'wîl, yaitu melalui mekanisme "mengembalikan atau memahami ayat yang mutashâbih kepada atau berdasarkan ayat mubkam". ${ }^{43}$ Ayat-ayat yang mubkam adalah ayat-ayat pembatal/penganulir (nâsikh), sedangkan ayat-ayat yang mutashâbih adalah ayat-ayat yang dibatalkan/teranulir (mansûkh), di mana posisi keduanya sama dengan posisi pokok (ash) terhadap cabang (far). Dari sini, muncul naskh sebagai mekanisme gerak perujukan (al-barakah al-marji'ŷah) yang menghubungkan yang cabang tersebut kepada pokoknya. Jadi, naskh adalah menggeser yang mutashâbih ke yang mubkam. ${ }^{44}$ Gerak bolak-balik ini dalam naskh sebagai

${ }^{39}$ A hhmad al-Bahrânî, al-Ta'wîl, 253.

${ }^{40}$ Menurut al-Bahrânî, istilah ibdâl(Q.16/70:101) semakna dengan inzâl. Ibid., 400-422.

${ }^{41}$ Ibid., 254.

${ }^{42}$ Ibid., 41. Lihat juga Muhammad Hâdî Ma’rifah, al-Tambîd, vol. 2 (Qom: Mu'assasat al-Nashr al-Islâmî, 1411 H), 275 dengan merujuk Tafsîr al-'Ayyâshî̀, vol. 1, 12. Al-Bahrânî menyebut pencerita tersebut sebagai ahli fiqh rasional (faqîh al-ra'y) dan Hâdî Ma'rifah menyebut "pemutus hukum" (kadi, qâdhin).

${ }^{43}$ Metode ini konon dikatakan berasal dari sabba Nabi Muhammad: "inna fí al-Qur ân mutashâbih(an) wa mubkam(an), faman

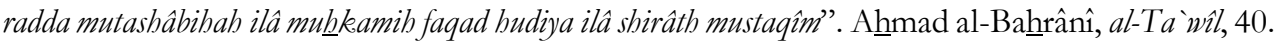

${ }^{44}$ Ibid. 
ta'wîl muncul dari asal kata ta'wîl sendiri yang berasal dari dua kemungkinan: dari kata awwal (jّ" awal) atau dari ma'âl (Jĩ,tempat kembali) dan ditarik dari sejumlah ayat al-Qur'an (seperti Q.29/ 85:20) sehingga ta'wîl bukan hanya sebagai mekanisme perujukan, yaitu mengembalikan yang mutashâbih ke mubkam, melainkan juga sebagai gerak kembali ke titik-awal ( ta'wîl adalah sebagai berikut: ${ }^{46}$

Skema:

Gerak ta'wîl menurut al-Bahrânî

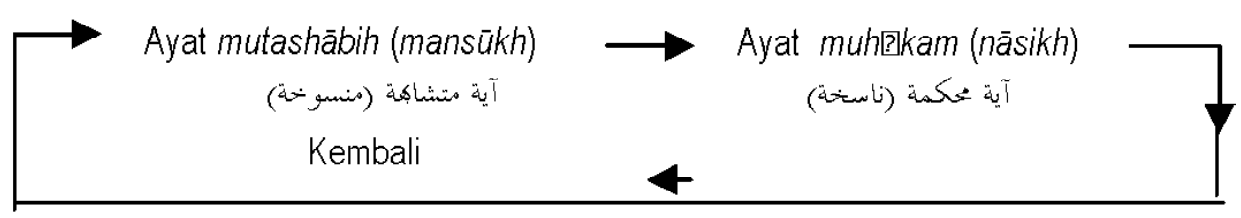

Menurut al-Baḩrânî, unsur-unsur yang harus ada dan menjadi bagian esensial ta wâlladalah sebagai berikut. Pertama, ayat yang dita'wîl sebagaimana ditunjukkan oleh makna etimologisnya (tanda, isyarat, atau simbol) pada dasarnya mencakup semua wujud. Akan tetapi, dalam konteks struktur al-Qur'an, ayat meliputi hurup alfabet, kata, ungkapan kalimat, termasuk titik. Itu artinya bahwa suatu kata atau kalimat bisa dilihat tidak hanya sebagai suatu ayat, melainkan pada saat yang sama adalah beberapa ayat. ${ }^{47}$ Perluasan cakupan ayat ini tampak muncul dari kritiknya terhadap ide tentang keterbatasan teks (mablûdîyat al-nashsh) yang sejak klasik dikemukakan oleh al-Juwaynî dari Sunnî, dan juga dianut

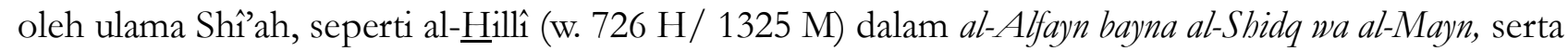
ulama Shî'ah modern yang dipengaruhi oleh al-Thûsî. ${ }^{48}$ Pandangan yang bertentangan dengan aliran (madrasah) Abl al-Bayt ini, menurutnya, adalah kreasi pemikiran (wadh'ŷah), tanpa dasar dalam agama, karena menganggap teks (nashsh) tidak bisa menjawab banyak persoalan. ${ }^{49}$ Kedua, naskh-ib̆kâm. Menurut al-Bahrânî, naskh tidak hanya berarti "menghilangkan" (izâlah), melainkan juga "menetapkan" (tathbît), "mengganti" (ibdâl, tabdî̉), dan "memindah" (naq). Makna-makna yang muncul dari analisis kebahasaan ini, sebagaimana dijelaskan oleh Ibn Manzhûr, menunjukkan bahwa teks (nashsh) mengalami gerakan melalui pembatalan, penetapan, penggantian, dan pemindahan, di mana semua makna tersebut dominan pada makna "mengganti" (ibdâl). Aktivitas naskh-iblkâm berarti adalah mengembalikan ayat mutashâbih sebagai cabang (far') ke ayat mubkam sebagai pokoknya (ashb), sama dengan mekanisme mengganti-menetapkan. ${ }^{50}$ Ketiga, meneliti kesamaan (istiqrâ' al-tamâthul), yaitu upaya mengidentifikasi ayat-ayat yang memiliki kesamaran maknanya dengan kemungkinan makna-makna lain, seperti dimungkinkan oleh adanya kata, kalimat, atau sinonimitas. Mekanisme ini adalah kerja logika (qiyâs tamthîlî). Al-tamâthul juga berarti adanya hubungan kesamaan antar ayat-ayat al-Qur'an sehingga bisa dianggap saling menjelaskan karena memiliki hubungan yang terlihat, misalnya, dari temanya. ${ }^{51}$

${ }^{45}$ Ibid., 516. Menurut al-Râghib, kata “ta 'wîl” sebenarnya berasal dari “awl” (kembali), yaitu bentuk mashdar dari âla-ya'ûlu, kemudian menjadi awwala-yu'amwilu, bukan dari kata awwal. Lihat al-Mufradât (Cairo: al-Maktabah al-Tawfîqîyah, t.th.), 40-41.

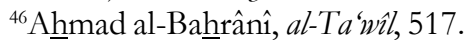

${ }^{47}$ Ibid., 361.

${ }^{48}$ Ibid., 248-249.

${ }^{49}$ Ibid., 250. Al-Bahrânî mengemukakan bukti holistisitas nashsh al-Qur'an dalam menjawab banyak persoalan dengan beberapa ayat al-Qur'an (Q.16/70:89; Q.al-Zukhruf: 63; al-An'âm: 38 dan 59; dan Yâsîn: 12) dan kutipan pendapat imam-imam Shî’ah.

\footnotetext{
${ }^{50}$ Ibid., 363-366.
}

${ }^{51}$ Ibid., 367-368. 
Keempat, ₹̧âhir-bâthin, yaitu bahwa setiap ayat dianggap memiliki aspek-aspek (wujûh) makna lahir dan makna batin. Berbeda dengan tanæîl yang terbatas pada aspek makna lahir, ta 'wîladalah pemaknaan yang "menyeberang" dari makna lahir ke makna batin, dari suatu aspek ke aspek makna lain. ${ }^{52}$ Kelima, penyimpulan fatwa (istinbâth al-fatwâ), yaitu bahwa ta'wîl bertujuan agar teks bisa berbicara memberikan jawaban atas persoalan yang muncul. ${ }^{53}$

Menurut al-Bahrânî, ta'wîl bisa bergerak dari tiga media atau yang disebutnya sebagai struktur, yaitu struktur bahasa (bun-yat al-lughah) al-Qur'an, struktur akal (bun-yat al-'aqD), dan struktur alam (bun-yat al-kawn). ${ }^{54}$ Hubungan tiga struktur tersebut dalam mencari aspek-aspek makna yang tepat pada kata dan ungkapan (tashrîf wujûh al-kalimah/al-ibârah)" didasarkan atas dasar "penggantiansaling menyempurnakan" (ibdâl-takâmul). Dalam hal hubungan ayat-alam, misalnya, ta'wîl bergerak dengan dua bentuk. Pertama, ta'wîl ayat al-Qur'an yang mutashâbih dengan ayat kawnîyah yang mublkam yang, menurutnya, didasarkan atas pernyataan Ibn 'Abbâs, "sesungguhnya al-Qur'an ditafsirkan oleh zaman" (inna al-Qur'ân yufassirub al-zamân). Kedua, ta'wîl ayat kawnîyah yang mutashâbih dengan ayat alQur'an yang mubkam yang didasarkan atas pernyataan Ibn 'Abbâs, "sesungguhnya al-Qur'an menafsirkan zaman" (inna al-Qur'ân yufassir al-zamân). Kedua model ta'wîl ini bisa dijelaskan dalam skema berikut: ${ }^{56}$

Skema:

Gerak Ta'wîl Ayat al-Qur'an - Ayat Kawnîyah

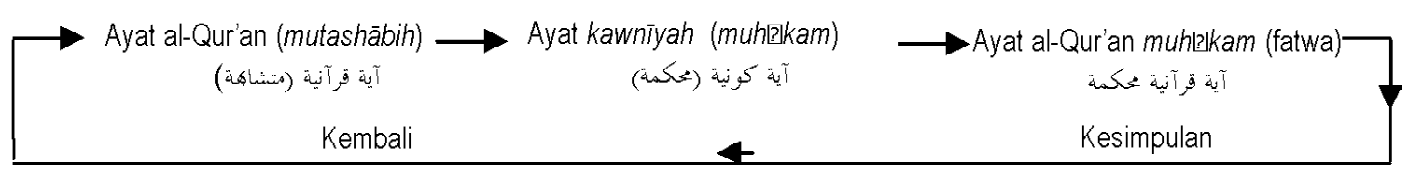

Skema:

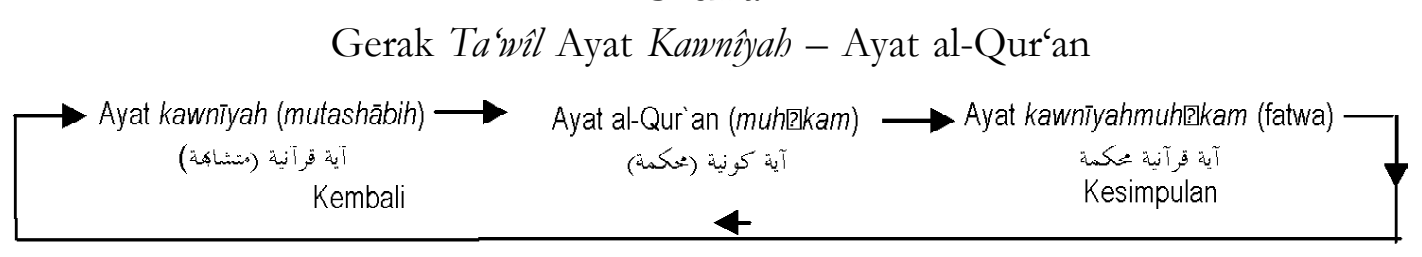

Di samping tiga struktur yang diklaim al-Bahrânî sebagai kerangka epistemologis (ną̧harîyat alma'rifah), ta'wîl ayat al-Qur'an juga bisa dilakukan dengan hadîth dengan empat pola naskh, yaitu hadîth - hadîth, hadîth - al-Qur'an, al-Qur'an - al-Qur'an, dan al-Qur'an - $\underline{\text { hadîth. }}{ }^{57}$

Berkaitan dengan fungsionalisasi naskh sebagai metode ta'wîl yang ditawarkan oleh al-Bahrânî, kita bisa memberikan catatan. Pertama, prinsip bahwa ayat mutashâbih harus dita'wûl berdasarkan pengertian ayat mubkam bisa dipahami, karena didukung oleh pemahaman bahwa sebagai umm alkitâb (pokok, ash), wajar jika ayat mubkam harus dirujuk di satu sisi, identifikasi mubkam-

\footnotetext{
${ }^{52}$ Ibid., $370-371$.

${ }^{53}$ Ibid., 372-376.

${ }^{54}$ Ibid., 509-515.

${ }^{55}$ Tentang "tashrîf al-wujûh", lihat ibid., 428-435. Dari segi bahasa, tashriffbermakna memalingkan, membolak-balik, atau mengubah-ubah arah. Pengertian ini menjadi makna dasar dari ta ‘n̂́l sebagai mencari makna lebih dalam dan esensial dari sekadar makna lahiriah (z?âhir) ke makna dalam (bât?in).

${ }^{56}$ Ibid., 532.

${ }^{57}$ Lihat uraian teoretis, skema ta ${ }^{6} \mathfrak{\imath} l$, dan contoh penerapan model ini dalam ibid., 551-569.
} 
mutashâbihsebagai nâsikh-mansûkh juga muncul sebagai penafsiran di kalangan mufassir awal, seperti al-Dhahhâk. ${ }^{58}$ Prinsip ini dikenal di kalangan sebagian Sunnî, ${ }^{59}$ semisal tampak pada pernyataan tentang mubkam sebagai "patokan yang dirujuk oleh ayat lain dengan ta'wîl' ('umdah yuraddu ilayhâ ghayrubâ bi al-ta'wî́) dan yang semaknanya yang didukung oleh Haqqî Ismâ'îl, al-Baydhâwî, al-Nawawî, dan alNasafî, ${ }^{60}$ meski penerapannya di kalangan Mu’tazilah dan Shî̀ah tampak lebih menonjol. Fungsionalisasi naskh seperti ini memiliki akar kesejarahan dan doktrinal lebih menonjol di kalangan Mu'tazilah. Teologi Shî’ah dan Mu'tazilah terbukti dalam sejarah berafiliasi, seperti tampak misalnya pada masa Dinasti Buwayh. ${ }^{61}$ Orisinalitas metode ta $w \hat{\imath} l$ ini adalah bahwa mekanisme perujukan itu tidak linear, melainkan sirkular. Kedua, penerapan metode ini rentan menjadi sarana justifikasi ideologis saja, seperti tampak dalam argumen teologi Mu’tazilah. Kontroversi ulama terjadi tidak hanya dalam mendefinisikan dan kemungkinan menafsirkan ayat mutashâbihb, ${ }^{62}$ melainkan juga menentukan kedua kategori ayat tersebut. Level kontroversi ini menjadikan persoalan ini kemudian dianggap nisbi, tergantung atas pemahaman dan perspektif dalam menafsirkan ayat. ${ }^{63}$ Penentuan ayat-ayat mubkam dan mutashâbih, akhirnya, menjadi pilihan ideologis. ${ }^{64}$

\section{Naskh sebagai Metode Pengembangan Hukum Islam}

Tak pelak lagi bahwa naskh difungsikan dalam konteks pengembangan hukum Islam. Naskh dalam 'ulum al-Qur'ân sebagai pembatalan antarayat diperluas penerapannya dalam ushûl al-fiqh. Ketika terjadi kontradiksi makna (ta'ârudh) yang gagal dikompromikan (jam', tawfíq), naskh dijadikan sebagai salah satu metode penyelesaian dengan menganggap salah satu di antara dalil lebih awal dibandingkan

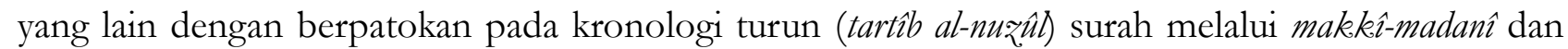
keterangan riwayat. ${ }^{65}$ Sejak al-Shâfi'î, metode naskeh berkembang secara ekstensif tidak hanya naskh antarayat al-Qur`an, melainkan juga isu kontroversi melebar ke naskhsunnah, ijmâ', dan qiyâs. Al-

${ }^{58}$ al-Suyûthî, al-Itqân fì 'Ulùm al-Qur ân, vol. 1, 3 .

${ }^{59}$ al-Suyûthî (ibid., vol. 1, 2) menyebutkan salah satu definisi muh?kam sebagai "ayat yang berdiri sendiri”" (mastaqalla binafsih) dan mutashâbih sebagai "ayat yang tidak berdiri sendiri, kecuali dengan dikembalikan kepada ayat lain" (mâ lâ yastaqill bi nafsih illa biraddih ilâ ghayrih). Lihat juga al-Jashshâsh, A $\underline{b}$ âm al-Qur ân, vol. 2, ed. Muhammad al-S?âdiq Qamhâwî, (Beirut: Dâr Inyâ`al-Turâth al-'Arabî, 1405 H), 282-284.

${ }^{60}$ Leah Kinberg, "Mublkamât and Mutashâbihât (Koran 3/7): Implication of a Koranic Pair of Terms in Medieval Exegesis”, dalam Andrew Rippin (ed.). The Qur an: Formative Interpretation(USA/Singapore/Sydney: Ashgate, 1999$), 162$.

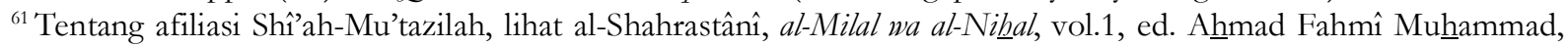
(Beirut: Dâr al-Kutub al-'Ilmîyah, 1992), 22; Joel L. Kraemer, Humanism in the Renaissance of Islam: the Cultural Revival During the Buyid Age (Leiden: E. J. Brill, 1986), 72.

${ }^{62}$ Lihat al-Suyûthî, al-Itqân fî̀ Ulûm al-Qur ân, vol. 1, 2-3; Leah Kinberg, "Mublkamât and Mutashâbihât (Koran 3/7): Implication of a Koranic Pair of Terms in Medieval Exegesis", dalam Andrew Rippin (ed.), The Qur an: Formative Interpretation (USA/Singapore/Sydney: Ashgate, 1999), 283-312. Mayoritas kaum muslim (sahabat, tâbi'ûn, dan mayoritas aliran Abl al-Sunnah) tidak melakukan ta wîl. Di kalangan mereka, berlaku kaedah tentang prioritas makna haqî qî atas majâzî́, seperti diformulasikan oleh Ibn al-Arabî bahwa "kewajiban menempatkan ungkapan-ungkapan pada makna-makna lahiriahnya yang layak" (wujûb tanzîl alalfâ̧̧̧ 'alâ ma'ânîhâ al-z̧hâhirah fîhâ al-lâ iqah). Lihat Ibn al-'Arabî, al-Nâsikh wa al-Mansûkh, 139. Sedangkan, kalangan Mu'tazilah melakukan ta mîllebih intensif.

${ }^{63}$ Kaedah, "al-Qur`an semuanya mulbkam dilihat dari suatu cara pandang tertentu, semuanya mutashâbih dilihat dari cara pandang tertentu, atau sebagiannya mublkam, dan sebagiannya mutashâbih dilihat dari cara pandangan ketiga (yang lain)” (al-Qur 'ân al-karîm kulluh mubkam bi'tibâr, wa kulluh mutashâbih bi'tibâr, wa ba'dhuh mubkam wa ba'dhuh mutashâbih bi'tibâr thâlith). Khâlid bin 'Uthmân al-Sabt, Qawẩid al-TafsîrJam'an wa Dirâsah, vol. 2 (Mesir: Dâr ibn 'Affân, 1421 H), 661.

${ }^{64}$ Misalnya: Q.7:143 dan Q.6:104 tentang kemungkinan melihat Allah (ru'yat Allâh) dan Q.18:29 dan Q.76:30 tentang kemandirian (qadar) dan ketergantungan (jabr) manusia.

${ }^{65}$ Lihat lebih lanjut uraian tentang hal ini dari perspektif usûl al-fiqh perbandingan dalam 'Abd al-Lathîf 'Abdullâh 'Azîz al-Barzanjî̀, al-Ta'ârud? wa al-Tarjîh bayna al-Adillah al-Shar'îyah: Baḅth Ushûlî Muqâran bi al-Madhâhib al-Islâmîyah al-Mukhtalifah, vol. 1 (Beirut: Dâr al-Kutub al-'Ilmîyah, 1993), 310-336. 
Shâfi'î sendiri sebagai pioner metode ini menetapkan kontradiksi antarayat pada level makna "nashsh". Mayoritas mubaddithûn dan fuqahâ dari kalangan Shâfi'îyah, Hanafîyah, Ja'farîyah, dan Mu'tazilah menolak kebolehan "ta wîl yang jauh" (ta 'wîl ba'îd) yang dipaksakan untuk mengkompromikan. ${ }^{66}$ Namun, fanatisme aliran fiqh menggeser pandangan ini dan naskh digunakan untuk menjustifikasi pandangan madhhab, seperti tampak dalam pernyataan Abdullâh al-Karkhî (w. $340 \mathrm{H}$ ), seorang $\underline{\text { Hanafí, }}$ "Pada prinsipnya, setiap ayat yang bertentangan dengan pendapat para pengikut madbhab kami harus dianggap mansûkh atau harus ditarjîh. Yang lebih utama adalah dita 'wîl untuk melakukan kompromi”

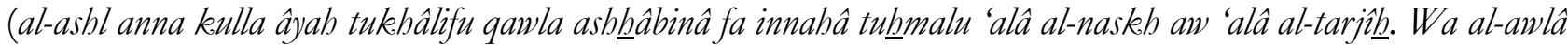
an tubmal 'alâ al-ta' wîl min jihat al-tawfíq). ${ }^{67}$

Di kalangan ahli tafsir dan ushâl al-fiqh kemudian muncul dualitas makna naskh sebagai "pembatalan final" dan "penundaan" yang berpatokan pada kronologi turun (tartîb al-nuzû́) surah dan kesadaran tentang mashlabah sebagai esensi pembatalan tersebut. Pergeseran trend ini, sebagaimana dikemukakan, mengalami beberapa fase. Sambil mengakui naskh sebagai pembatalan final, al-Zarkashî dalam al-Burbân mengemukakan konsep tentang adanya hukum yang ditunda pelaksanaannya karena bersifat kondisional-temporal. Konsep "pembatalan final-penundaan” ini lebih komprehensif kemudian dikemukakan oleh al-Biqâ̂i dalam Naz̧bm al-Durar dan Ibn 'Âshûr dalam al-Tậrî wa alTanwîr. Meski mengakui terjadinya kontradiksi antarayat, mereka juga memahami bahwa pembatalan tersebut pada substansinya adalah pergeseran mashlabah yang menjadi alasan penundaan. Dengan dipengaruhi oleh 'Abduh, M. Quraish Shihab mengemukakan konsep tabdîl pada tataran substansi ayat sebagai "pembatalan temporal-penundaan" dan menolak "pembatalan final". Pemikiran M. Quraish Shihab tampak sebagai transisi atau menengahi antara pembatalan final-penundaan al-Zarkashî, al-Biqâ̂̀, dan Ibn 'Âshûr dengan konsep "penundaan" Abû Zayd yang melihat teks dalam dimensi kesejarahannya yang selalu diproyeksikan ke realitas yang selalu berubah. Secara revolusioner, ide serupa diturunkan dalam konteks privatisasi sharîah untuk kepentingan kebebasan, keadilan, dan kesetaraan sipil secara revolusioner diusung oleh Thâhâ, kemudian diikuti oleh an-Naim. Belakangan dalam konteks pergulatan pemikiran hukum di tanah air, ide tentang mashlabah sebagai poros pergeseran hukum juga diangkat sebagai dasar pembatalan nashsh dengan formulasi "kebolehan membatalkan nashsh-nashsh dengan mashlabah" (jawâz naskh al-nushûsh bi al-mashlabah) oleh komunitas muda Nahdhatul Ulama yang diklaim gerakan pemikirannya sebagai "postradisionalisme". Meski sejalan dengan Najm al-Dîn al-Thûfî (w. 716 H) tentang mendahulukan mashlabah atas teks, tapi proyek pemikiran ini ditujukan mengkritisi anggapan tentang tidak mungkinnya terjadi pertentangan antara teks (nashsh) dan mashlabah yang didasarkan anggapan keliru bahwa teks adalah mashlabah itu sendiri.

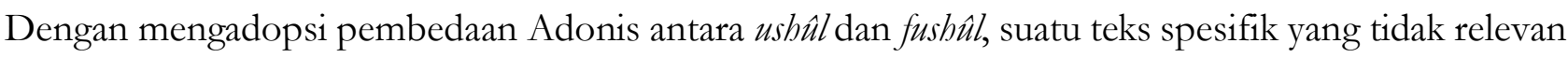
lagi dilihat dari perspektif mashla $\underline{h} a h$ bisa dianulir dengan teks yang keberlakuannya didasarkan atas nilai-nilai universal. ${ }^{68}$ Pembedaan Ibn al-Muqaffa'-dikutip melalui al-Thâbit wa al-Mutahawwil Ado-

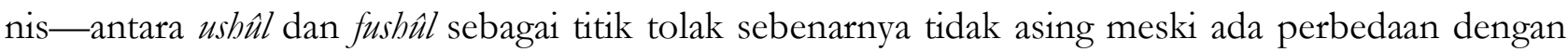
pembedaan al-Shâthibî antara ayat kullî dan juž îyang kemudian menjadi dasar penyimpulan qawẩid kulliyahnya, atau pembedaan Fazlur Rahman antara dimensi ajaran al-Qur`an yang bersifat universal

${ }^{66}$ Lihat 'Abd al-Lat?îf 'Abdullâh 'Azîz al-Barzanjî, al-Ta'ârud?, 228-234.

${ }^{67}$ Sebagaimana dikutip oleh Shaykh Aḥmad bin al-Shaykh Muhammad al-Zarqâ, Sharh al-Qawâ'id al-Fiqhîyah, ed. 'Abd alSattâr Abû Ghuddah (Damaskus: Dâr al-Qalam, 1996), 39; Muhammad Husayn al-Dhahabî, al-Tafsîr wa al-Mufassirûn, vol. 2 (Beirut: Dâr al-Fikr, 1976 M/ 1396 H), 434.

${ }^{68}$ Lihat Rumadi, "Post Tradisionalisme Islam: Wacana Intelektualisme dalam Komunitas NU”, (Disertasi, Sekolah Pascasarjana Universitas Islam Negeri Syarif Hidayatullah, Jakarta, 2006), 361-363. 
yang disebutnya sebagai ideal-moral dan yang bersifat spesifik yang disebut sebagai legal-specific. Bahkan, penerapan naskh ini juga tidak berbeda jauh dari apa yang ditawarkan oleh Thâhâ berkaitan dengan naskh âyat al-ushûl terhadap âyât al-furû' atas dasar mashlabah yang kontekstual diukur dari hukum waktu. Dengan berpatokan pada kerangka ush $\hat{u} l-f u r u \hat{\prime}$ dan bergerak pada logika, bukan pada kronologi turun surah (tartîb al-nu₹ûh), seperti kebolehan nikah beda agama, metode naskh ini diproyeksikan dalam konteks liberalisme hukum di Indonesia. ${ }^{69}$

Pergeseran sangat signifikan tampak pada konsep "pembatalan temporal” al-Bahrânî yang dikemukakan di atas. Meski memiliki alur pikir yang sama dengan T?âhâ, an-Naim, dan Abû Zayd, al-Bahrânî mengemukakan konsep naskh sebagai metode ta wîl ayat-ayat mutashâbih, baik ayat hukum maupun non-hukum secara lebih komprehensif dan sistematits. Meski demikian, metode tersebut, semisal preferensi makna bathin atas zhâhir ayat, jelas diproyeksikan sebagai rasionalisasi doktrin Shî̀ah, seperti halnya Mu’tazilah.

Tabel:

Model Fungsionalisasi Naskh dalam Hukum Islam

\begin{tabular}{|c|c|c|c|c|c|c|c|}
\hline \multicolumn{2}{|l|}{ Trend } & Model & Faktor & Materi & $\begin{array}{c}\text { Kerangka } \\
\text { Pikir }\end{array}$ & Proyeksi & Pengusung \\
\hline \multirow{6}{*}{ 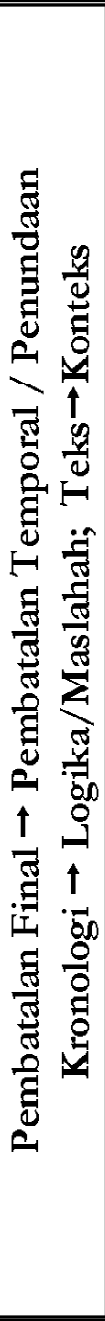 } & 1 & - Pembatalan final & $\begin{array}{l}\text { - Kontradiksi } \\
\text { antar ayat }\end{array}$ & • Hılkım & $\begin{array}{l}\text {-Makki-madanī; } \\
\text {-Kctcrangan } \\
\text { riwayat }\end{array}$ & $\begin{array}{l}\text {-Solısi } \\
\text { kontradik } \\
\text { si dalìl } \\
\text { - Penbelaa } \\
\text { n } \\
\text { madhhab } \\
\text { figh }\end{array}$ & $\begin{array}{l}\cdot \text {-al-Shăfìi } \\
\text {-Mayoritas } \\
\text { ulama }\end{array}$ \\
\hline & 2 & $\begin{array}{l}\text { - Pembatalan } \\
\text { final } \\
\text { - Pclupaan } \\
\text { - Penundaan }\end{array}$ & $\begin{array}{l}\text { - Kontradiksi } \\
\text { antar ayat } \\
\text { - Trrclcransi } \\
\text { kandungan } \\
\text { ayat dg kondisi }\end{array}$ & $\begin{array}{l}\text {-Hukum } \\
\text {-Non- } \\
\text { hı1kım }\end{array}$ & $\begin{array}{l}\text {-Makkī-madanī; } \\
\text { - Keterangan } \\
\text { riwayat } \\
\text {-Mashlahah- } \\
\text { mafsadah }\end{array}$ & $\begin{array}{l}\text { Solusi } \\
\text { kontradik } \\
\text { si dali1 } \\
\cdot \text { Kontekst } \\
\text { ualisasi } \\
\text { Hukum } \\
\end{array}$ & 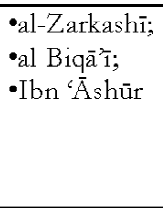 \\
\hline & & $\begin{array}{l}\text { - Pembatalan } \\
\text { temporal } \\
\text { - Penundaarı }\end{array}$ & $\begin{array}{l}\text { - Kesamaran } \\
\text { makna ayat }\end{array}$ & $\begin{array}{l}\text { • Mutashābi } \\
\text { h: hukumn } \\
\text { danı non- } \\
\text { hukum }\end{array}$ & $\begin{array}{l}\text { •Muhkam- } \\
\text { mutashābih } \\
\text { •Makná zhāhir- } \\
\text { bāthin }\end{array}$ & $\begin{array}{l}\cdot \text { Ta wìl } \\
\text { ayat yang } \\
\text { berkaitan } \\
\text { dengan } \\
\text { ajaran } \\
\end{array}$ & $\begin{array}{l}\text {-al-Bahnrānī } \\
\text {-Mu'tazilah } \\
\text {-Sh'in'ah }\end{array}$ \\
\hline & & $\begin{array}{l}\text { - Pernbalalan } \\
\text { temporal } \\
\text { - Pcnundaan }\end{array}$ & $\begin{array}{l}\text { - Irrelevanısi } \\
\text { kandungan } \\
\text { ayat dg kondisi }\end{array}$ & $\begin{array}{l}\text {-Hukuin } \\
\text {-Non- } \\
\text { hukum }\end{array}$ & $\begin{array}{c}\text {-Mashlahiahl- } \\
\text { matsadah }\end{array}$ & $\begin{array}{l}\text { Konntekst } \\
\text { ualisasi } \\
\text { Hukum }\end{array}$ & $\begin{array}{l}\text {-Abduh, } \\
\text {-M. Quraish } \\
\text { Shihab; } \\
\text {-Abü Zayd }\end{array}$ \\
\hline & 3 & $\begin{array}{l}\text { - Pembatalan } \\
\text { temporal } \\
\text { - Penundaan }\end{array}$ & $\begin{array}{l}\text { - Irelevansi } \\
\text { kandungan } \\
\text { ayat dg kondisi }\end{array}$ & -Hukum & $\begin{array}{l}\text {-Mashlahah- } \\
\text { mafsadah } \\
\text { - Maqasid } \\
\text { Sharīah } \\
\text {-Ayal ushoūl- } \\
\text { fushūl }\end{array}$ & $\begin{array}{c}\cdot \text { Liberalisa } \\
\text { si hukum }\end{array}$ & $\begin{array}{l}\text {-Postradision } \\
\text { a-lisme }\end{array}$ \\
\hline & & $\begin{array}{l}\text { - Pembatalan } \\
\text { temporal } \\
\text { - Penundaan }\end{array}$ & $\begin{array}{l}\text { - Irrelevansi } \\
\text { kandungan } \\
\text { ayat dg kondisi }\end{array}$ & $\begin{array}{l}\text { • Hukum } \\
\text { •Non- } \\
\text { hukum }\end{array}$ & $\begin{array}{l}\text { - Hukum waktu } \\
\text { - Risalah } \\
\text { pertama-kedua } \\
\text {-Ayat usū furū' }\end{array}$ & $\begin{array}{l}\cdot \text { Evolusi } \\
\text { sharīah } \\
\text {-Privatisasi } \\
\text { hukum: } \\
\text { kebebasa } \\
\mathrm{nl}, \\
\text { keadilan, } \\
\text { dan } \\
\text { kesetaraa } \\
\mathrm{n} \text { sipil }\end{array}$ & 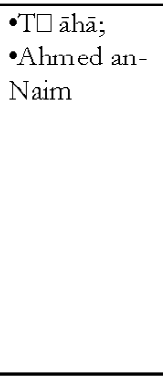 \\
\hline
\end{tabular}

${ }^{69}$ Lihat Abdul Moqsith Ghazali, Argumen Pluralisme Agama: Membangun Toleransi Berbasis al-Qur'an (Jakarta: Kata Kita, 2009), 340-346. 
Dari tabel di atas, tampak trend pemikiran tentang naskh secara umum dan aplikasinya dalam konteks hukum secara khusus memiliki kecenderungan (1) dari pembatalan final (naskh muthlaq) ke pembatalan temporal (naskh mu'aqqat) yang disertai penundaan penerapan kandungan hukum ayat yang dibatalkan tersebut; (2) dari patokan kronologi ke logika atau mashlabah; (3) dari teks ke konteks, seperti dipertimbangkan "hukum waktu" ( ulama bahwa, selain kompleksitas dan konsekuensi-konsekuensi luas yang diakibatkan oleh pembatalan final, esensi pembatalan tersebut sesungguhnya adalah perubahan isi (content) ayat, bukan ayat itu sendiri, sehingga mashlabah yang merupakan elan dasar pergeseran tersebut juga bergeser karena perubahan ruang dan waktu. Konsep "penundaan” ini lebih merupakan bentuk revisi kalangan revisionis, bahkan cenderung merupakan ide alternatif sebagai penolakan terhadap naskh klasik, karena esensi penundaan adalah bagaimana suatu kandungan ayat dipandang relevan dengan konteks ruang-waktu, jadi sebenarnya fokus persoalan adalah penerapan kandungan ayat dalam konteks, bukan soal pembatalannya.

\section{Penutup}

Dari uraian yang telah dikemukakan di atas, tampak bahwa naskh difungsionalisasikan untuk berbagai kepentingan ideologis. Sejak awal, athar yang menopang tentang keharusan mempelajari naskh tidak memiliki validitas yang kuat. Dengan ditopang oleh athar tersebut, naskh sebagai metode penafsiran al-Qur'an berkembang, termasuk di kalangan Shi'ah yang menerapkannya sebagai metode ta'wil ayat-ayat yang dianggap ambigu. Sejak al-Shafi'i menjelaskan naskh sebagai metode dalam penyimpulan hukum Islam, penggunaan metode ini tidak terlepas dari berbagai konteks kepentingan ideologis hingga perkembangan kontemporer.

\section{Daftar Pustaka}

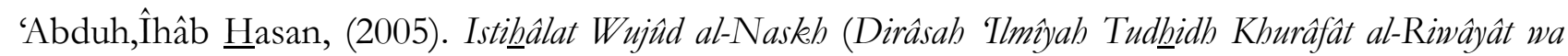
Taruddu 'alâ Jahl Zakariyyâ Buthrus. Cairo: Maktabat al-Nâfidhah.

Abû 'Ubayd, (2006). Kitâb al-Nâsikh wa al-Mansûkh, suntingan (tạqqî) Mushthafâ 'Abd al-Qâdir 'Athâ'. Beirut: Dâr al-Kutub al-'Ilmîyah.

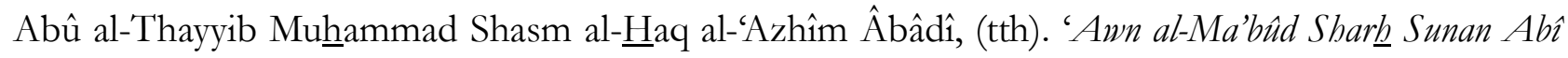
Dâwûd, vol. 10, ed. 'Abd al-Rahnmân Muhammad 'Uthmân. Beirut: Dâr al-Fikr.

Abû Nu'aym, (1988). Hilyat al-Awliyâ' wa Thabaqât al-Ashfiyấ, vol. 3.Beirut: Dâr al-Kutub al-'Ilmîyah.

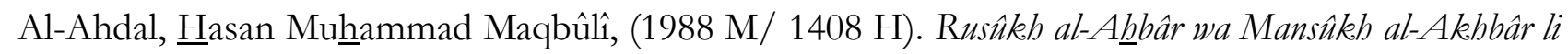

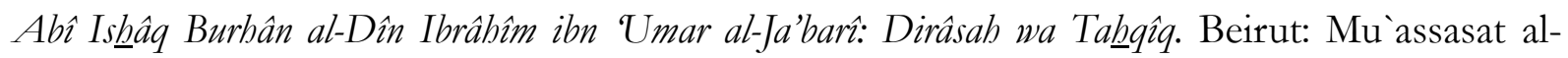
Kutub al-Thaqâfîyah dan San'â: Maktabat al-Jîl al-Jadîd.

Al-Baghdâdî, (tth). 'Abd al-Qâhir al-Nâsikh wa al-Mansûkh, suntingan (tậqîq) Hilmî Kâmil As'ad 'Abd al-Hâdî. Aman: Dâr al-'Adawî.

Al-Baghawî, (1993). Ma'âlim al-Tanẑ̨l, vol. 2. Beirut: Dâr al-Kutub al-'Ilmîyah.

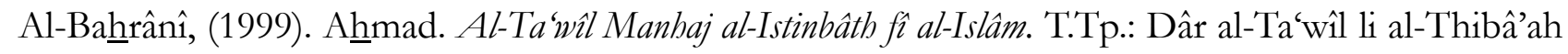
wa al-Nashr. 
Al-Barzanjî, 'Abd al-Lathîf 'Abdullâh 'Azîz, (1993). Al-Ta'ârudh wa al-Tarjî̀ bayna al-Adillah al-Shar'îyah: Bahth Ushûlî Muqâran bi al-Madhâhib al-Islâmîyah al-Mukhtalifah, vol. 1. Beirut: Dâr al-Kutub al'Ilmîyah

Al-Bukhârî, (1407 H/ 1987 M). Shahîhal-Bukhârî, anotasi (ta'lîq) Mushthafâ Dîb al-Bighâ, vol. 3. Beirut: Dâr Ibn Kathîr.

Al-Bûthî, Munammad Sa'îd Ramadhân, (1990). Al-Salafîyah: Marhalah Zamanîyah Mubârakah, Lâa Madhhab Islâmî. Damaskus: Dâr al-Fikr.

Al-Dhahabî, Muhammad ㅂusayn, (1976 M/ 1396 H). Al-Tafsîr wa al-Mufassirûn, vol. 2. Beirut: Dâr al-Fikr.

Al-Dhahabî, Syams al-Dîn, (1997).Ma'rifat al-Qurrâ' al-Kibâr 'alâ al-THabaqât wa al-A'shâr. Beirut: Dâr al-Kutub al-'Ilmîyah.

Al-Fawzân, Shâlih bin Fawzân bin 'Abdullâh, (1411 H). Ta'qîbât' 'alâ Kitab al-Salafìyah Laysat Madhhaban. Riyâdh: Dâr al-Wathan li al-Nashr.

Ghazali, Abdul Moqsith, (2009). Argumen Pluralisme Agama: Membangun Toleransi Berbasis al-Qur'an. Jakarta: Kata Kita.

Gilliot,Claude, (1999). “The Beginnings of Qur’ânic Exegesis”, dalam The Qur an: Formative Interpretation, ed. Andrew Rippin. Great Britain: Ashagate.

Hibatullâh ibn Salâmah. Al-Nâsikh wa al-Mansûkhh, suntingan (tậqîq) Zuhayr al-Shâwîs dan Muhammad Kan'ân. Beirut: al-Maktab al-Islâmî, 1404 H.

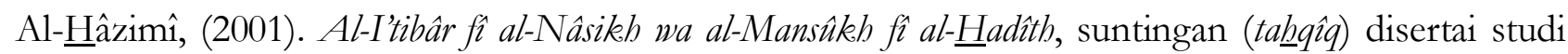
A hlmad Thanthâwî Jawharî Musaddad. Makkah: al-Maktabah al-Makkîyah dan Beirut: Dâr Ibn Hazm.

-, (1986). al-Nâsikh wa al-Mansîkh fî al-Qure

Ibn Abî Shaybah, (1994). Al-Mushannaf fî al-Ahâdîth wa al-Âthâr, vol. 6. Beirut: Dâr al-Fikr.

Ibn al-Jawzî, (tth). Nawâsikeh al-Qư'ân. Dâr al-Kutub al-'Ilmîyah.

--, (tth).Talbîs Iblîs, ed. Muhyî̀ al-Dîn Muhammad Ba’yûn. Beirut: Dâr Ibn Zaydûn.

Ibn Kathîr, (1988). Tafsîr al-Qur'ân al-'Az̧hîm. Beirut: Dâr al-Fikr, t.th.

Ibn Qutaybah. Ta'wîl Mukhtalif al- $\underline{H}$ adîth. Cairo: Mu'assasat al-Kutub al-Thaqâfîyah.

Ibn Shâhîn, Abû $\underline{H} a f s ~ ' U m a r ~ b i n ~ A \underline{h m a d, ~(2008) . ~ N a ̂ s i k h ~ a l-\underline{H} a d i ̂ t h ~ w a ~ M a n s u ̂ k h u h, ~ e d . ~ a l-S H a ̂ d i q ~ b i n ~}$ 'Abd al-Rahnmân al-Gharayânî. Beirut: Dâr Ibn 프azm.

Al-Ishfahânî, Al-Râghib, (t.th). Al-Mufradât fi Gharîb al-Qur'ân. Cairo: al-Maktabah al-Tawfîqîyah.

'Ismâ'îl, Sha'bân Muhammad, (1988). Nazharîyat al-Naskh fî al-Sharầi' al-Samâwîyah. T.tp.: Dâr alSalâm. 
Al-Jashshâsh, (1405 H). A $\underline{h} k$ âm al-Qur'ân, vol. 2, ed. Muhammad al-Shâdiq Qamhâwî. Beirut: Dâr Ihyâ' al-Turâth al-'Arabî.

Al-Karamî, Yûsuf. Qalâ'id al-Marjân fî Bayân al-Nâsikh wa al-Mansûkh fî al-Qur'ân, dalam www.elmeshkat.com.

Al-Khâzin, (1995). Lubâb al-Ta'wn̂l fì Ma'ânî al-Tanzîl. Beirut: Dâr al-Kutub al-'Ilmîyah.

Al-Khû'î, al-Sayyid Abû al-Qâsim al-Mûsawî, (1998). The Prolegomena to the Qur'an, terj. disertai pengantar oleh Abdulaziz A. Sachedina. Oxford: Oxford University Press.

Kinberg, Leah, (1999)."Mubkkamât and Mutashâbihât (Koran 3/7): Implication of a Koranic Pair of Terms in Medieval Exegesis", dalam Andrew Rippin (ed.). The Qur'an: Formative Interpretation. USA/Singapore/Sydney: Ashgate.

Ma’rifah, Munhammad Hâdî, (1411 H). Al-Tambîdfî Ulûm al-Qur'ân, vol. 2.Qom: Mu`assasat al-Nashr al-Islâmî.

Al-Mizzî, (1982). Tahdhîb al-Kamâl, ed. Bashshâr 'Awwâd Ma’rûf. Beirut: Mu`ssasat al-Risâlah.

Al-Munhâsibî, (1982). Fahm al-Qur'ân, ed. ㅂusayn al-Quwwatilî. Beirut: Dâr al-Fikr dan Dâr al-Kindî. Al-Nahhâs, (tth). Al-Nâsikh wa al-Mansûkh. Cairo: al-Maktabah al-Azharîyah.

Nasr, Seyyed Hossein, (1996). “The Meaning and the Concept of Philosophy in Islam,” dalam History of Islamic Philosophy, ed. Seyyed Hossein Nasr dan Oliver Leaman. London dan New York: Routledge.

Al-Qurthubî, (tth). Al-Jâmi’ li Albkâm al-Qurân.T.tp.: t.p.

Rippin, Andrew, (1984). "Al-Zuhrî, Naskh al-Qur ân, and the Problem of Early Tafsîr Text”, dalam Bulletin of the School of Oriental and African Studies, University of London, volume 47, no. 1.

Rumadi, (2006). "Post Tradisionalisme Islam: Wacana Intelektualisme dalam Komunitas NU", disertasi. Jakarta: Sekolah Pascasarjana Universitas Islam Negeri Syarif Hidayatullah.

Al-Sabt, Khâlid bin 'Uthmân, (1421 H). Qawâid al-TafsîrJam'an wa Dirâsah, vol. 2. Mesir: Dâr ibn 'Affân.

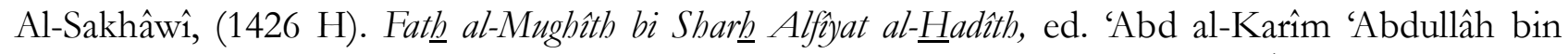
'Abd al-Rahnmân al-Khudhayr dan Muhammad bin 'Abdullâh bin Fuhayd Âl Fuhayd. Riyâdh: Maktabat Dâr al-Minhâj.

Sezgin, Fuat, (1967). Geschichte des Arabischen Schrifttums.Leiden: E.J. Brill.

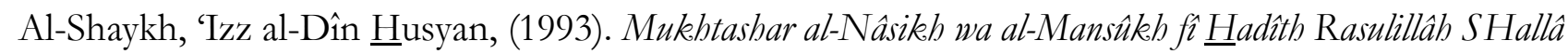
Allâh 'Alayh wa Sallam. Beirut: Dâr al-Kutub al-'Tlmîyah.

Shu'lah, Abû 'Abdillâh, (1995). Shafwat al-Râsikh fî Tlm al-Mansûkhh wa al-Nâsikeh. T.tp.: Maktabat alThaqâfah al-Dînîyah. 
Al-Suyûthî, Jalâl al-Dîn, (2003). Al-Durr al-Manthîr, ed. 'Abdullâh bin 'Abd al-Muhsin al-Turkî, vol. 14. Cairo: Markaz li al-Buhûth wa al-Dirâsât al-'Arabîyah wa al-Islâmîyah.

-, (thh). Al-Itqân fî̀ Ulûm al-Qur ân, vol. 1. Beirut: Dâr al-Fikr.

--, (2003).Tadrîb al-Râwî fî̀ Sharh Taqrîb al-Nawâwî̀, ed. al-Shaykh 'Arafât al-'Ashshâ Hishshûnah. Beirut: Dâr al-Fikr.

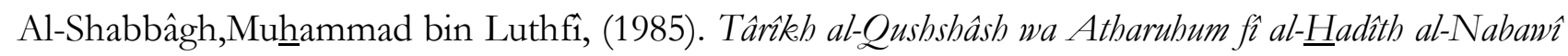
wa Ra'y al-'Ulamâ' fỉhim. al-Maktab al-Islâmî.

Wansbrough, John, (1977). Quranic Studies:Sources and Methods of Scriptural Interpretation. Oxford: Oxford University Press.

Al-Zarkashî, Badr al-Dîn, (1957 M/ 1376 H). Al-Burhân fî̀ 'Ulûm al-Qur'ân, ed. Muhammad Abû alFadhl Ibrâhîm. Cairo: Dâr Inyâ' al-Kutub al-'Arabîyah.

Al-Zarqâ, Muhammad, (1996). Sharh al-Qawâ'id al-Fiqhîyah, ed. 'Abd al-Sattâr Abû Ghuddah. Damaskus: Dâr al-Qalam.

Zayd, Mushthafâ, (2007). Al-Naskh fî al-Qur'ân al-Karîm: Dirâsab Tashrîŷyah Târîkhîyah Naqdîyah. Cairo: Dâr al-Yusr. 